\title{
Appendixes
}

\section{Some historical documents}

\section{A1 - Franco-German intergovernmental agreement}

\section{Agreement between the government of the French Republic and the government of the Federal Republic of Germany on the construction and operation of a very high flux reactor.}

et

Le Gouvernement de la République Française

Le Gouvernement de la République Fédérale d'Allemagne,

- soucieux de poursuivre la mise en application des dispositions du Traité franco-allemand du 22 janvier 1963, en particulier, de celles relatives au développement de la coopération scientifique entre les deux pays,

- considérant l'intérêt des recherches qui ont déjà été effectuées tant en France qu'en République Fédérale d'Allemagne dans le domaine de la physique nucléaire et de la physique du solide,

- constatant, qu'en Europe, des installations nouvelles sont nécessaires au développement de ces recherches,

- désireux que d'autres Etats européens puissent participer aux actions qu'ils se proposent d'entreprendre en commun, ont décidé de promouvoir la construction et l'exploitation à des fins pacifiques d'un réacteur à très haut flux de neutrons et sont en conséquence convenus des dispositions suivantes:

\section{ARTICLE I}

La construction et l'exploitation du réacteur qui fait l'objet de la présente convention sont confiées à une société civile dont les associés sont la Société à responsabilité limitée "Gesellschaft für Kernforschung $\mathrm{mbH}^{\prime}$ ", d'une part, le "Commissariat à l'Energie Atomique" et le "Centre National de la Recherche Scientifique", d'autre part.

La Société dont les statuts sont déposés auprès des deux gouvernements:

- n'entreprendra d'activités qu'à des fins pacifiques,

- est désignée sous le nom d'“Institut Max von Laue - Paul Langevin",

- aura son siège à Grenoble,

- sera dirigée par une haute personnalité scientifique allemande,

- utilisera pour ses travaux la langue française et la langue allemande, en outre:

- les membres français et allemands du Comité de direction de la Société ne peuvent être nommés et révoqués qu'avec l'accord de leur Gouvernement respectif; 
- les litiges survenus entre les associés sont soumis aux gouvernements lorsqu'ils n'ont pu être réglés à l'amiable;

- les associés demanderont l'approbation conjointe des gouvernements pour toute modification des statuts;

- de nouveaux associés pourront être admis une fois que la construction du réacteur, de ses installations annexes et de ses dispositifs d'expérimentation sera achevée.

\section{ARTICLE II}

1. Les deux Gouvernements s'engagent à mettre à la disposition des associés:

- d'une part, une somme de 163 millions de francs français (132 millions de DM) destinée à couvrir les dépenses de construction du réacteur.

- d'autre part, et à concurrence de 43 millions de francs français (35 millions de $\mathrm{DM}$ ) une subvention annuelle destinée à couvrir les dépenses d'exploitation.

2. Chaque Gouvernement participe pour moitié aux dépenses prévues à l'article II paragraphe 1 ci-dessus. Toutefois pendant la phase d'exploitation du réacteur dont le début est fixé par le Comité de direction de la Société, les dépenses de fonctionnement sont réparties à raison de $49 \%$ pour le Gouvernement de la République Fédérale d'Allemagne et de $51 \%$ pour le Gouvernement de la République Française. Le montant de cette participation de chacun des gouvernements devra tenir compte de certaines recettes fiscales perçues par chacun des deux Etats à l'occasion de la création et du fonctionnement de la Société.

3. Si le montant des dépenses est supérieur aux sommes fixées au paragraphe 1 ci-dessus, les deux Gouvernements après avoir pris l'avis des organes compétents de la Société, se consulteront pour déterminer les moyens de poursuivre en commun la construction et l'exploitation du réacteur. Les deux Gouvernements se consulteront également si les taux de change en vigueur lors de la conclusion de la présente convention viennent à varier.

4. Les deux Gouvernements s'assurent que les sommes mises la disposition de la Société pour la construction et l'exploitation du réacteur sont employées dans les conditions les meilleures et prennent les mesures nécessaires à cet effet.

\section{ARTICLE III}

Sous réserve des exigences de l'ordre public et de la sécurité publique, chaque Gouvernement s'engage à faciliter le déplacement et le séjour des nationaux de l'autre partie contractante employés par la Société ou qui seront appelés par elle à effectuer des travaux de recherches.

\section{ARTICLE IV}

1. La présente convention est ouverte à l'adhésion des Etats tiers. Toute adhésion doit recueillir l'agrément des Gouvernements signataires. Les conditions de l'adhésion font l'objet d'un accord entre les Gouvernements signataires et le Gouvernement de l'Etat adhérent.

2. Au cas où les autres Etats membres de la Communauté Européenne de l'Energie Atomique souhaiteraient adhérer à la Convention, les deux Gouvernements 
s'efforceraient de placer les activités de la Société dans le cadre du programme de recherches établi par cette Communauté.

\section{ARTICLE V}

1. Les différends relatifs à l'interprétation ou à l'application des dispositions de la présente convention seront réglés par voie de négociation entre les deux Gouvernements.

2. Si les deux Gouvernements ne parviennent pas à un accord sur la solution d'un différend, chacun d'eux peut soumettre celui-ci à la décision d'un Tribunal d'arbitrage composé de trois membres.

3. Chaque partie contractante désigne dans un délai d'un mois un arbitre; les deux arbitres ainsi désignés choisissent parmi les ressortissants d'un Etat tiers, dans un délai de deux mois à compter de leur nomination, un surarbitre qui assumera les fonctions de président du Tribunal d'arbitrage.

4. Si les délais prévus à l'alinéa 3 ne sont pas observés et à défaut d'un autre arrangement, chaque partie pourra prier le Président de la Cour de Justice des Communautés Européennes de procéder aux nominations nécessaires.

5. Le Tribunal d'arbitrage prend ses décisions à la majorité des voix.

6. Le Tribunal d'arbitrage prend ses décisions sur la base des dispositions de l'article 38 paragraphe $1 \mathrm{du}$ Règlement de la Cour Internationale de Justice. Ses décisions sont obligatoires.

7. Le Tribunal fixe ses règles de procédure selon les modalités prévues au chapitre 3 du Traité de La Haye du 18 Octobre 1907.

8. Chaque partie prend à sa charge ses propres frais et la moitié des frais du Tribunal d'arbitrage.

9. Les dispositions du présent article, à l'exception de celles du paragraphe 6 ci-dessus, sont applicables lorsque des différends surviennent entre les associés au sujet du fonctionnement de la Société et doivent être soumis à leurs Gouvernements en vertu de l'article 24 des Statuts. Le Tribunal délibère sur la base des règles de droit applicables au litige considéré.

\section{ARTICLE VI}

La Présente Convention s'appliquera également au Land de Berlin sauf déclaration contraire faite par le Gouvernement de la République Fédérale d'Allemagne au Gouvernement de la République Française dans les trois mois qui suivront l'entrée en vigueur de la présente convention.

\section{ARTICLE VII}

1. La présente Convention entrera en vigueur dès que les deux Gouvernements se seront mutuellement informés de l'accomplissement des procédures constitutionnelles nécessaires à cet effet.

2. La présente Convention est conclue pour une durée de 13 ans. A l'expiration de ce délai, elle sera prorogée d'année en année par tacite reconduction et ne pourra être dénoncée qu'avec un préavis d'un an. 
En foi de quoi, les représentants des deux gouvernements ont signé la présente convention et y ont apposé leur sceaux.

Fait à Grenoble, le 19 Janvier 1967, en double exemplaire en langue française et en langue allemande, les deux textes faisant également foi.

Pour le Gouvernement de la République Française

Alain PEYREFITTE

Ministre Délégué Chargé de la recherche Scientifique

et des questions atomiques et spatiales

Pour le Gouvernement de la République Fédérale d'Allemagne

G. STOLTENBERG

Ministre fédéral de la recherche scientifique

\section{A2 - Activity report by Maier-Leibnitz 1968}

Activity report presented by Maier-Leibnitz in 1968 in which he outlined his vision of what the Institut Laue-Langevin should be. The text is left unchanged (with minor errors in French). I think it was written directly in French.

Institut Max von Laue - Paul Langevin, Grenoble 13 Novembre 1968.

Le rôle du Réacteur à Haut Flux dans la recherche de la matière solide et liquide. Par le Prof. Maier-Leibnitz

\section{A2.1 Général}

L'utilisation des neutrons lents permet un nombre d'expériences spéciales et parfois uniques dans le domaine de la recherche fondamentale. Le Réacteur à Haut Flux étant la source la plus forte du monde de tels neutrons, a été choisi, après de longues discussions qui ont commencé dans le cadre de l'OECD, comme instrument qui est suffisamment grand pour être utilisé par les chercheurs de plus d'une nation et qui peut stimuler la recherche dans des champs intéressants, surtout sur l'état solide où, après les travaux fondamentaux d'il y a 40 ans, les contributions provenant de l'Europe n'ont pas connu un accroissement aussi important qu'on voit dans les grands pays et qui semble être justifié là et par le progrès dans notre connaissance de la matière et par la multitude d'applications.

\section{A2.2 Les autres Laboratoires du Réacteur}

Les grands réacteurs (surtout Brookhaven et Oak Ridge) donnent autant de neutrons que le réacteur proposé pour Grenoble et l'on pourrait penser que - avec un délai de cinq 
ans avec ces réacteurs - il ne restera plus beaucoup de travail intéressant. Nous avons dû regarder ce point avec attention, en utilisant notre expérience approfondie avec un réacteur et notre connaissance d'un grand nombre d'autres réacteurs. Certes, beaucoup de beau travail est fait sur les réacteurs existants. Pourtant, partout, ou presque partout, on pourrait faire mieux. A tout réacteur on peut trouver une des objections qui suivent:

1. Souvent, le réacteur sert en première ligne pour les irradiations, loops, production d'isotopes, mesures de réactivité, etc., et le travail sur faisceaux de neutrons n'a pas assez de priorité pour bien pouvoir utiliser l'équipement et le temps des chercheurs. Parfois, l'esprit d'ambiance n'est pas favorable à la recherche pure. Cela peut décourager les scientifiques, surtout ceux qui ne sont pas eux-mêmes "du métier".

2. La plupart des expériences utilisant les réacteurs, sauf peut-être sur la diffraction des neutrons, sont encore faites par les spécialistes de la physique des neutrons et non pas les physiciens des champs comme la physique du solide, d'où les bons problèmes prennent leur origine.

3. Dans beaucoup de laboratoires, la théorie est trop faible, ce qui conduit à un choix des expériences souvent sans bonne relation avec le "courant" du progrès en physique.

4. Presque partout, les réacteurs sont "sous-peuplés" de scientifiques. Le rendement des installations coûteuses pourrait être bien meilleur s'il y avait assez de physiciens pour faire ces mesures nuit et jour, pour vraiment évaluer les résultats, pour trouver des problèmes nouveaux et pour élaborer des méthodes perfectionnées.

5. Sauf quelques exceptions remarquables, il n'a pas été possible de créer une organisation d'accueil pour les scientifiques visiteurs appartenant aux universités et aux autres laboratoires.

6. Il nous semble que presque partout, les méthodes d'expérimentation ne sont pas à la hauteur du perfectionnement du réacteur même. C'est peut-être dû au nombre relativement faible des chercheurs utilisant un réacteur (en comparaison, par exemple, avec les accélérateurs), que la plus grande partie de l'équipement est relativement conservateur et non optimisé.

Dans beaucoup de cas, la recherche de meilleures méthodes montre qu'il faudrait faire des changements sur les réacteurs ou même sur les bâtiments ou sur le site qui ne sont plus possible après la construction.

\section{A2.3 Le Réacteur à haut flux de l'Institut Laue-Langevin}

1. Les considérations esquissées ci-dessus nous ont guidées dans tous nos plans pour le Réacteur. Surtout, nous avons prévu, ou espérons obtenir, les conditions suivantes, favorables, nous l'espérons, pour la réussite de notre entreprise.

a. Le Réacteur est, comme d'ailleurs à Brookhaven H.F.B.R., destiné à la recherche seulement. Il est un réacteur à faisceaux de neutrons;

b. Des irradiations seront possibles pour un nombre limité d'échantillons de petites masses pour ne pas interférer avec le fonctionnement des expériences sur canaux. 
2. Le bâtiment réacteur contient une surface pour expériences plus vaste que les autres réacteurs (diamètre de $60 \mathrm{~m}$ ). Cette surface est séparée de la surface d'exploitation. Le plan expérimentateur est au niveau d'un remblai à l'extérieur; cela permet de faire passer les neutrons hors du bâtiment jusqu'à plus de 500 mètres (expériences de temps de vol, etc.).

3. Le Réacteur, avec sa protection, les canaux, les conduits de neutrons, la source froide et la source chaude ont été projetés en coopération avec les expérimentateurs, futurs utilisateurs du réacteur. Nous pensons que le réacteur offrira un nombre d'avantages pour ces derniers. Nous espérons pouvoir installer un nombre optimum d'expériences (peut-être 40) autour du réacteur, et on pourra appliquer un nombre de techniques qui ne sont pas possibles sur les autres réacteurs.

Voici une liste non complète des avantages:

- Flux de neutrons constant (barre de contrôle à l'intérieur du cœur). Protection importante pour réduire le bruit de fonds dans le hall et au dehors.

- Niches près des canaux pour installations variables près du cœur, avec protection du sable fluidisé.

- Source froide (50 fois plus d'intensité pour les neutrons très lents).

- Source chaude (20 fois plus d'intensité autour de $500 \mathrm{meV}$ ).

- Canaux à ouverture $230 \mathrm{~mm}$ hors de la zone $\mathrm{D}_{2} \mathrm{O}$.

- Canal transversal avec suppression de toute radiation directe du cœur du réflecteur.

- Canal vertical semi-traversier à grande ouverture.

- 10 conduits de neutrons $3 \times 16 \mathrm{~cm}$ : suppression de tout bruit de fonds non causé par les neutrons lents, augmentation de la surface utile pour faisceaux sortant; long parcours sans perte d'intensité pour temps de vol. Séparation des expériences dans l'espace.

4. En même temps, avec le projet du réacteur, le travail a commencé sur les appareils pour expériences. Après discussion des méthodes nouvelles ou améliorées utilisant des conduits de neutrons, des systèmes de cristaux monochromateurs, des méthodes de temps de vol, des systèmes de détecteurs multiples, etc., par ces développements, coûteux, mais pas coûteux en comparaison avec le coût annuel du réacteur, nous espérons gagner autant en intensité ou en résolution pour nos expériences que par le réacteur même.

\section{A2.4 Organisation du travail scientifique}

Le nombre de chercheurs qui pourront travailler à Grenoble ne peut évidemment pas être fixé aujourd'hui, mais nous pensons qu'il sera autour de 200 dont 50 à 70 pour cent visiteurs. Nous espérons qu'un nombre important parmi eux pourra être des boursiers de thèses pour que notre Institut puisse contribuer à la formation des jeunes dans un domaine moderne et important.

Le budget (sans tout ce qui est exploitation du réacteur "Reaktorbetrieb", mais avec salaires, dépenses pour expériences nouvelles et existantes, nouveaux bâtiments après 
la première tranche) sera de 25 millions de francs environs par ans, ce qui devrait être en bonne relation avec le nombre de chercheurs.

Quand le réacteur sera prêt en 1969, on aura un bâtiment laboratoires de $3000 \mathrm{~m}^{2}$ environ et un hall d'essais pour grandes expériences, des ateliers, etc. On espère profiter de la coopération avec le CENG et avec les laboratoires de Grenoble du CNRS pour les grands ateliers, l'électronique, les basses températures, les ordinateurs, la préparation des cristaux, etc. Mais nous savons que cette coopération requiert que nous soyons partie prenante, et que les contributions venant de notre Institut doivent être attractives pour nos partenaires.

Structures d'accueil. Tout nouveau venu est frappé par la complexité des expériences autour d'un réacteur, par les précautions qu'il faut prendre et par les techniques qui sont peu connues à la plupart des chercheurs mais dont la tradition et le développement font le secret du succès d'un laboratoire de réacteur. C'est pourquoi il faut faire tout, pour donner aux chercheurs, et surtout à ceux qui viennent d'autres laboratoires, toute information et aide pour leur expérience. Les méthodes à suivre ne sont pas encore élaborées. Nous pensons aux stages suivants:

- Informations sur les recherches semblables à l'expérience proposée: discussion et optimalisation de la méthode.

- Dessins et peut-être construction à Grenoble de certaines parties de l'appareil, surtout la partie en pile et la protection. Peut-être coordination par un "project engineer" comme à Oak-Ridge.

- Aide pendant l'expérience par les techniciens, et si nécessaire par les chercheurs de l'Institut.

- Evaluation des données par les méthodes développées par l'institut pour toutes les expériences.

Relations avec les autres laboratoires. Le programme autour du réacteur est la plus grande responsabilité du Conseil Scientifique qui est composé de 16 membres, moitié français, moitié allemands. La plupart des membres ne sont pas membres de l'Institut Laue-Langevin. Ils sont réélus tous les deux ans, et nommés par le Comité de direction, organe suprême. Dans la première phase qui n'est pas encore déterminée, la grande partie du programme a été, outre le travail de définir quelques caractéristiques du réacteur, de décider sur le choix d'appareils et de méthodes pour les futures expériences. Après cette phase, et commençant maintenant, la tâche importante est l'élaboration du programme scientifique. Le Conseil scientifique reçoit et considère toute proposition d'expériences provenant d'autres pays sera possible dans le futur, et la coopération avec des individus chercheurs est toujours sans formalité).

Le Conseil scientifique a quatre sous-comités: diffusion élastique (diffraction et diffusion à petits angles), diffusion inélastique, évaluation des données, physique nucléaire. Pour le moment, l'activité de ces comités concerne en première ligne le choix et le développement d'appareils autour du réacteur.

Pour le moment, les "neutronistes" dominent dans ces comités parce qu'ils connaissent les possibilités et les problèmes d'un réacteur. Mais dans le futur, la situation sera différente. On espère que les deux tiers environ des expériences au réacteur seront proposées par les chercheurs qui ne sont pas membre de l'Institut Laue-Langevin et seront exécutés, soit par eux-mêmes avec l'aide technique dont on a parlé plus haut, soit 
par eux, en collaboration avec les chercheurs de Grenoble. Dans quelques cas, il sera possible de faire des mesures "sur commande" avec des substances qui sont envoyées par un laboratoire.

Quand le réacteur sera prêt, on aura un comité des utilisateurs présidé par un chercheur venant de l'extérieur pour assigner les positions et appareils au réacteur, le temps pour la préparation, les mesures et l'aide technique.

Le Conseil scientifique, quand à lui, pourra bientôt changer de composition pour mieux représenter les utilisateurs non spécialistes du réacteur.

Nous sommes très conscients du fait que, même si la valeur exceptionnelle du réacteur pour la recherche est connue, il n'est pas facile de convaincre les chercheurs qui sont contents de leur travail dans leurs propres laboratoires, qu'il vaille la peine d'élargir leur activité, de former un groupe pour Grenoble, de trouver des problèmes qui peuvent être résolus avec le réacteur, ou même d'inventer des expériences nouvelles.

Nous ferons un effort de bien informer tous ceux qui pourront s'intéresser au réacteur. L'année prochaine, on aura la première école d'été qui nous permettra d'initier une quarantaine d'étudiants aux applications du réacteur pour la physique des solides et liquides. Nous pouvons offrir d'inviter les intéressés de venir à Grenoble pour un séjour court ou plus long, ou de venir nous-mêmes aux autres laboratoires pour discuter de nos problèmes. On commence maintenant à Grenoble d'avoir des séminaires réguliers sur la physique du solide en vue de nos applications, avec une audience très limitée il est vrai pour le moment, et nous espérons étendre cela dans le futur.

Un effort relativement important a déjà commencé, c'est le travail d'un groupe de théorie qui, dans notre opinion, est indispensable pour développer un bon programme. En regard à la situation particulière de Grenoble, ce groupe a commencé à Munich. Il comprend maintenant des théoriciens. Cette année, on a eu un programme de visites de ces théoriciens à Grenoble, où quelques-uns seulement travaillent en permanence. On espère pouvoir obtenir une répartition entre Munich et Grenoble au cours de l'année prochaine; en même temps qu'une augmentation vers le nombre final qui sera vingt.

\section{A3 - Visit of SRC 6-7 March 1970 - Conclusions (Jolliffe)}

I would summarise my impression thus:

1. Despite difficulties of Franco-German collaboration, the project seems to be going forward fast and smoothly and they hope it will be in operation by mid-1971.

2. It appears to be costing about $£ 25 \mathrm{M}$ capital and running costs are estimated at $£ 4 \mathrm{M}$.

3. Collaboration with UK, which would chiefly benefit UK for the next 5-7 years, was freely offered and warmly welcomed.

4. Detailed information was freely given and anything more we want was promised.

5. The success of the scheme so far is, in substantial measure, due to the Director, Prof Maier-Leibnitz and his policy of appointing able senior staff at an early stage. 


\section{A4 - Letter from Flowers to Creyssel in January 1972}

This telex was sent in January 1972 from Brian Flowers to Pierre Creyssel, Head of the Steering Committee. I have reproduced with no comments the text as it was forwarded by Creyssel to the 24 other members of the Steering Committee on the 23 or 24 January 1972.

Editor's Note: Like any telex of the time, the original text was written in uppercase. However, to make the text more readable, we have reproduced a transcription using conventional typography.

May I start by congratulating your election as president of the ILL and wishing the institute every success in the new year.

At our meeting on 14 December we explored most of the possibilities for collaboration between the Franco-German ILL and the SRC on the provision of high flux neutron beams. My summary of the meeting was:

The French and German representatives rejected the exploratory proposal which the SRC had made in Grenoble for a collaborative high flux neutron beam programme based on partenership in the use proposed HFBR in the UK.

They did not think it necessary to decide on the building of a second high flux reactor for some years and in any case would not wish to combine irradiation facilities and neutron beam facilities in the same reactor. For the UK the AEA and SRC explained that the limited funds available made it important to provide both irradiation and neutron beam facilities in the proposed programme and that experience proved it perfectly satisfactory to provide both in one reactor.

You stressed the desirability of the SRC becoming a full partner in the ILL as soon as possible.

You proposed that the SRC should pay, in addition to its one-third share of the budget less taxes agreed each year, an initial capital contribution of $13 \mathrm{M}$ Francs a year at January 1972 prices for ten years. You assessed this as being to equivalent to about $72 \%$ of a full one-third share of the capital cost. If the SRC joined ILL, France and Germany would agree, for a number of years to be determined, to undertake high flux neutron beam research only in collaboration with the UK. If, during that period, it were decided to build a second reactor jointly, that reactor would be in UK.

The French and German representatives recognised that the decision of how best to provide high flux neutron beam facilities posed severe problems for the UK. They therefore indicated that if, having joined the ILL, the SRC still wished to carry out the design study of the HFBR, they might be willing to adjust the rate of payment of the annual contribution towards the capital costs of Grenoble reactor. This might enable the capital contribution in 1972 and 1973 at a lower rate than 13 M Francs a year.

The SRC appreciated the proposals described in (b) and (c) but, as became clear after the recess, the funds available for the UK programme were not sufficient to 
enable the SRC to become a partner in ILL and also to collaborate with the AEA in pursuing the HFBR proposal.

Professor Maier-Leibnitz suggested that the possibility of converting the ILL into a widely based European organisation like CERN should be examined. Such an arrangement could help to resolve the SRC financial problem but both French and German representatives considered that it would be impraticable to widen the collaboration to such an extent.

As at earlier meetings, neither the French nor German representatives were authorised to discuss the SRC request for information about possible financial arrangements under which British scientists could be permitted to carry out an approved programme on the Grenoble reactor. The SRC had in mind the possible use of up to about $10 \%$ of the capacity under such arrangements.

The meeting ended without our being able to see a way to achieve a joint European programme which would satisfy the different requirements of France and Germany on one hand and the UK on the other. We therefore provisionally arranged to meet again on 2 February in case there were any further ideas for satisfying the different requirements in a single acceptable programme to discuss and in case The French and German representatives were by then authorised to discuss possible arrangements for a limited use of the Grenoble reactor by British scientists.

Since then, despite earnest consideration with AEA and other bodies concerned in the UK, the SRC has so far been unable to develop any praticable scheme which likely to meet both French and German wishes and the British needs. On the other hand, our annual revision of the whole financial programme is not yet far enough advanced to enable us to say whether any possible adjustement of the rate of SRC capital contributions towards the ILL could offer a way of resolving the difficulties. We should, therefore, on 2 February be unable to add anything substancial to what we said in Paris last month.

We would still welcome the meeting if you were able to discuss possible financial arrangements on the lines of those originally suggested by the SRC for limited use of the Grenoble reactor by British scientists or if you had succeeded in developing any new ideas. However, if the Franco-German partners in the ILL are, like SRC, unable to add to the views expressed at the December meeting, I suggest it would be best to postpone the proposed meeting for a few weeks. I would however suggest that if we do postpone the meeting we should aim for another date in April or May. 


\section{A5 - Fender: recommendation to build the synchrotron on the ILL site}

In this report recommending construction of the European synchrotron radiation source on the ILL site, the part which describes the applications of synchrotron radiation, has been omitted.

21 February 1984

\section{The European Synchrotron Source at the ILL}

\section{Introduction}

This paper proposes the European synchrotron source should be sited the Institut Laue-Langevin at Grenoble.

There are three main arguments:

1. The synergic effect of coupling the world's leading neutron research centre with a "state of the art" X-ray synchrotron source.

2. The ILL infrastructure is an excellent base for the new source. Technical expertise associated with neutron research is readily transferable. The site itself is welladapted to the proposed ESRF and considerable saving in time and money is possible.

3. The style of operation of the ILL: the international collaboration; the co-operation between visitor and in-house research; the provision of research facilities for long and short-term visitors, which lie at the heart of the Institut's success, are entirely appropriate to a synchrotron research centre - they provide the best possible general guarantees that the ESRF can be built up to be an equally effective Institute in the minimum time.

The combined effect of the ILL and the ESRF (called the Maxwell Institute for convenience) would be to create a centre for condensed matter and materials research quite unequalled anywhere else. The ILL already draws scientists from all over the world in collaborations with European scientists. The focussing effect of the ILL-Maxwell would be even greater and the influence on European research profound.

\section{The case for the European Synchrotron Source}

The detailed arguments for a 'state of the art' X-ray synchrotron source are advanced in several papers and are not restated here. We underline the simple point that the scattering of X-rays provides most of our direct information about the structure of substances down to the atomic level. Much of our understanding therefore in physics,

\section{Co-existence of the Maxwell Institute and the ILL}

It is important to emphasise that this proposal is not a take-over bid by the ILL for the ESRF. At first sight this view, taken with the arguments we have previously advanced, might seem to imply two distinct and apparently contradictory philosophies. One is to preserve a separate identity and independence for the new synchrotron source and the 
existing ILL; the second is to achieve the maximum scientific interaction and technical co-operation coupled with considerable financial and manpower savings. In fact the two aims can be achieved easily by adaptation of the existing ILL structure.

Independence is achieved for the new Maxwell Synchrotron Institute by the following major recommendations:

a) There should be a separate Directorate plus the Services of the Direction.

b) There should be a separate Scientific Council and sub-committee system.

c) The scientists, immediate technical support and Accelerator Department should be the separate responsibility of the Maxwell Institute.

d) A matching organisation is retained by the ILL with the Reactor Department instead of the Accelerator Department.

e) For these separate departments, and for ILL or Maxwell investments, individual budget lines would be provided, with transfers between Institutes only possible with the approval of the Steering Committee.

Several departments would be run jointly by the two institutes: Instruments and Methods, Site and Buildings, Computing and Administration. The management of these departments is ensured by the combined directorates meeting regularly with all Heads of Department and Senior Scientists.

\section{A6 - Intervention of Dr. Newport at the Steering Committee of 28 November 1991}

Dr. Newport's statement was as follows:

As the Associates will be aware, the Science and Engineering Research Council (SERC) has conducted a review of relative scientific priorities for future council support, having regard to known future resource availability. The Council has now concluded that financial expenditure on the neutron sources at ILL and ISIS should be reduced by $£ 5$ million per annum beyond previously planned levels with effect from 1994/1995. The resources so released would make possible the support of other high priority science.

In the light of its recent review of UK neutron science, the Council has further decided that financial support for the ISIS facility should remain broadly in line with currently planned levels. Accordingly, the SERC has advised the UK Government that it will need to seek a reduction in the level of the UK's contribution to the ILL, post 1993.

At present the ILL is out of commission for repairs, and is likely to remain closed for a considerable time. Subject to a satisfactory outcome to the present assessment of refurbishment costs for the reactor; agreement on how these costs should be met; and on future terms for membership, the UK would hope to see the refurbishment proceed and to remain a partner following re-commissioning.

It has to be emphasised, however, that the UK, with other Associates, will need to be finally satisfied about the level of refurbishment costs and the extent to which these can be met from within existing available resources. 


\section{A7 - Ipoustéguy's interpretation of the work he made for the ILL}

\section{The fulfilment of Man walking towards Unity}

1. The original fire

2. The creation of first member of mankind.

3. Prometheus (the liver eaten by a vulture).

4. The atomic bomb destroys man

- physically - legs torn off,

- genetically deformed limbs.

5. The young pregnant woman; strong hope of the new man looking towards the future. The onset of labour, legs apart for the birth of the child.

6. In labour belly extended. The frame represents the work needed for delivery.

7. The birth; the child with head down sent to his destiny, but attached to a framework, the lifetime of work which awaits.

8. The child becomes man:

- is going to enter the Institut (science, research),

- is protected from head to toe against the atom,

- is pushed by the right leg,

- is held back by the left leg,

- arms are stretched towards the future (where he's going),

- hands are raised in a gesture of fear; he fears what awaits while feeling obliged to go; that will be his future.

9. The Institut: his destiny of work is represented by a frame through which he must pass. 
